\title{
The efficacy of long-term oral anticoagulant therapy and its laboratory assessment
}

\author{
R. D. EASTHAM \\ From the Department of Pathology, Frenchay Hospital, Bristol
}

SYNOPSIS The activated partial thromboplastin time is compared with the corresponding prothrombin ratio in 6378 samples of platelet-poor plasma from 446 patients treated for a total of more⿻上丨 than 4500 patient/months with oral anticoagulants. A relative decrease in the activated partiaf

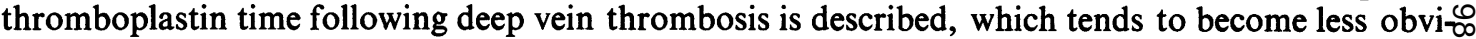
ous during the first year of treatment and is greater in older patients. Although this relative decrease is also found in patients treated after cerebrovascular accidents, it is not found in patients treatedafter myocardial infarction or in patients with mitral valve disease treated prophylactically with long-term oral anticoagulants. It is thought possible that these changes following deep vein throm bosis might be useful in helping to determine the duration of oral anticoagulant treatment.

Following the finding of a reduction in the activated partial thromboplastin time in various clinical conditions, including thrombosis, carcinoma, and acute haemorrhage, in the absence of anticoagulant therapy (Eastham and Morgan, 1964), a reduction in the activated partial thromboplastin time relative to the corresponding prothrombin ratio persisting in patients with venous thrombosis during longterm oral anticoagulant therapy was noted (Eastham, 1968). Later unsatisfactory attempts were made to define this finding using linear correlations between the prothrombin ratio and activated partial thromboplastin time (Eastham, 1970) and their ratios (Eastham, 1971).

The decision to start or stop oral anticoagulant treatment has involved a combination of empiricism and clinical judgment, balanced against the known risks inherent in such treatment. Results collected during six years from an outpatient anticoagulant clinic are reported here, with a further attempt to enable a laboratory assessment to be made of responses to long-term treatment of venous thrombosis.

\section{Patients}

Six thousand, three hundred and seventy-eight pairs of prothrombin ratios and their corresponding activated partial thromboplastin times were estimated in platelet-poor plasma samples taken from 446 Received for publication 19 November 1974. patients treated for more than 4500 patient/months during the six years 1967-1972.

\section{Methods}

Warfarin (or phenindione in the early stages of the 3 series) was given to maintain the activated partial? thromboplastin time within a range of 50 to 700 . seconds, using bentonite as surface activator with soya bean extract as platelet substrate substitute (Eastham, 1968). The prothrombin ratio was estimated, using rabbit brain thromboplastin (Diagen), which gave a range of $1 \cdot 3$ to $2 \cdot 1$ corresponding to윽 the recommended range of 1.8 to 3.0 of the British comparative thromboplastin, samples of which were? used regularly as references during the six years? (Poller, 1970).

To compare the prothrombin ratio and cor-N responding activated partial thromboplastin time results, a grid was constructed (fig 1), based on lines parallel to the linear correlations between thosec values obtained from patients treated with oralo anticoagulants following myocardial infarction, ino whom no venous thrombosis had been clinically obvious. An example of one such linear correlation ${ }^{+}$ is plotted and falls in the upper portion of the grid. Midway down the grid, a second example of a linear correlation is plotted, derived from results from a? patient during six years of treatment, who had previously developed thrombophlebitis soon after each attempt to discontinue anticoagulant therapy. 


\begin{tabular}{|c|c|c|c|c|c|c|c|c|c|c|c|c|c|c|c|c|c|c|}
\hline \multirow[t]{2}{*}{ Clinical Condition } & \multicolumn{3}{|c|}{ Patients } & \multicolumn{15}{|c|}{ Grid Area } \\
\hline & Male & emale & Total & $A$ & $\boldsymbol{B}$ & $C$ & $D$ & $E$ & $F$ & $G$ & $\boldsymbol{H}$ & $I$ & $\boldsymbol{J}$ & $\boldsymbol{K}$ & $L$ & $M$ & $N$ & Total \\
\hline $\begin{array}{l}\text { Postmyocardial infarction } \\
\text { Mitral valve disease } \\
\text { Cerebrovascular disease } \\
\text { Postvenous thrombosis } \\
\text { Totals }\end{array}$ & $\begin{array}{r}95 \\
20 \\
26 \\
130 \\
271\end{array}$ & $\begin{array}{r}10 \\
31 \\
11 \\
123 \\
175\end{array}$ & $\begin{array}{r}105 \\
51 \\
37 \\
253 \\
446\end{array}$ & $\begin{array}{r}16 \\
4 \\
1 \\
8\end{array}$ & $\begin{array}{r}32 \\
14 \\
1 \\
18\end{array}$ & $\begin{array}{l}54 \\
20 \\
11 \\
30\end{array}$ & $\begin{array}{l}91 \\
34 \\
14 \\
47\end{array}$ & $\begin{array}{r}129 \\
77 \\
33 \\
184\end{array}$ & $\begin{array}{r}415 \\
154 \\
84 \\
359\end{array}$ & $\begin{array}{l}580 \\
192 \\
146 \\
635\end{array}$ & $\begin{array}{l}445 \\
163 \\
172 \\
645\end{array}$ & $\begin{array}{r}216 \\
96 \\
128 \\
480\end{array}$ & $\begin{array}{r}83 \\
31 \\
49 \\
237\end{array}$ & $\begin{array}{l}35 \\
13 \\
19 \\
80\end{array}$ & $\begin{array}{r}9 \\
3 \\
17 \\
40\end{array}$ & $\begin{array}{r}2 \\
2 \\
3 \\
13\end{array}$ & $\begin{array}{l}1 \\
2 \\
2 \\
9\end{array}$ & $\begin{array}{r}2108 \\
805 \\
680 \\
2785 \\
6378\end{array}$ \\
\hline $\begin{array}{l}\text { Postmyocardial infarction } \\
15-100 \text { days } \\
101-200 \text { days } \\
201-300 \text { days }\end{array}$ & 37 & 5 & 42 & $\begin{array}{l}4 \\
1 \\
0\end{array}$ & $\begin{array}{l}7 \\
2 \\
2\end{array}$ & $\begin{array}{r}10 \\
2 \\
5\end{array}$ & $\begin{array}{r}21 \\
4 \\
6\end{array}$ & $\begin{array}{l}29 \\
18 \\
18\end{array}$ & $\begin{array}{l}63 \\
33 \\
30\end{array}$ & $\begin{array}{l}78 \\
43 \\
51\end{array}$ & $\begin{array}{l}72 \\
36 \\
34\end{array}$ & $\begin{array}{l}40 \\
17 \\
13\end{array}$ & $\begin{array}{r}17 \\
3 \\
4\end{array}$ & $\begin{array}{r}13 \\
1 \\
1\end{array}$ & $\begin{array}{l}2 \\
\mathbf{0} \\
\mathbf{0}\end{array}$ & $\begin{array}{l}1 \\
0 \\
0\end{array}$ & $\begin{array}{l}1 \\
\mathbf{0} \\
\mathbf{0}\end{array}$ & $\begin{array}{l}358 \\
160 \\
164 \\
682\end{array}$ \\
\hline $\begin{array}{l}\text { Postvenous thrombosis } \\
15-100 \text { days } \\
101-200 \text { days } \\
201-300 \text { days }\end{array}$ & 20 & 14 & 34 & $\begin{array}{l}0 \\
1 \\
0\end{array}$ & $\begin{array}{l}2 \\
1 \\
0\end{array}$ & $\begin{array}{l}5 \\
1 \\
0\end{array}$ & $\begin{array}{l}8 \\
1 \\
2\end{array}$ & $\begin{array}{r}35 \\
17 \\
7\end{array}$ & $\begin{array}{l}42 \\
25 \\
25\end{array}$ & $\begin{array}{l}82 \\
47 \\
53\end{array}$ & $\begin{array}{l}88 \\
48 \\
53\end{array}$ & $\begin{array}{l}76 \\
27 \\
29\end{array}$ & $\begin{array}{r}44 \\
9 \\
7\end{array}$ & $\begin{array}{r}12 \\
1 \\
2\end{array}$ & $\begin{array}{r}13 \\
0 \\
0\end{array}$ & $\begin{array}{l}6 \\
0 \\
1\end{array}$ & $\begin{array}{l}4 \\
0 \\
0\end{array}$ & $\begin{array}{l}417 \\
178 \\
179 \\
774\end{array}$ \\
\hline $\begin{array}{l}\text { Postvenous thrombosis } \\
20-49 \text { yr of age } \\
50+\text { yr of age }\end{array}$ & $\begin{array}{l}14 \\
66 \\
80\end{array}$ & $\begin{array}{l}35 \\
38 \\
73\end{array}$ & $\begin{array}{r}49 \\
104 \\
153\end{array}$ & $\begin{array}{l}1 \\
3\end{array}$ & $\begin{array}{l}3 \\
5\end{array}$ & $\begin{array}{r}2 \\
11\end{array}$ & $\begin{array}{r}7 \\
16\end{array}$ & $\begin{array}{l}31 \\
54\end{array}$ & $\begin{array}{l}50 \\
78\end{array}$ & $\begin{array}{r}94 \\
163\end{array}$ & $\begin{array}{r}68 \\
200\end{array}$ & $\begin{array}{r}52 \\
145\end{array}$ & $\begin{array}{l}17 \\
86\end{array}$ & $\begin{array}{r}8 \\
28\end{array}$ & $\begin{array}{r}5 \\
18\end{array}$ & $\begin{array}{l}2 \\
6\end{array}$ & $\begin{array}{l}0 \\
4\end{array}$ & $\begin{array}{r}340 \\
817 \\
1157\end{array}$ \\
\hline
\end{tabular}

Table I Frequency distributions in grid areas

The pairs of results were plotted on the grid and the frequency distributions in the various grid areas $(\mathrm{A}, \mathrm{B}, \mathrm{C}, \ldots \mathrm{N})$ were obtained for the various clinical groups (table I).

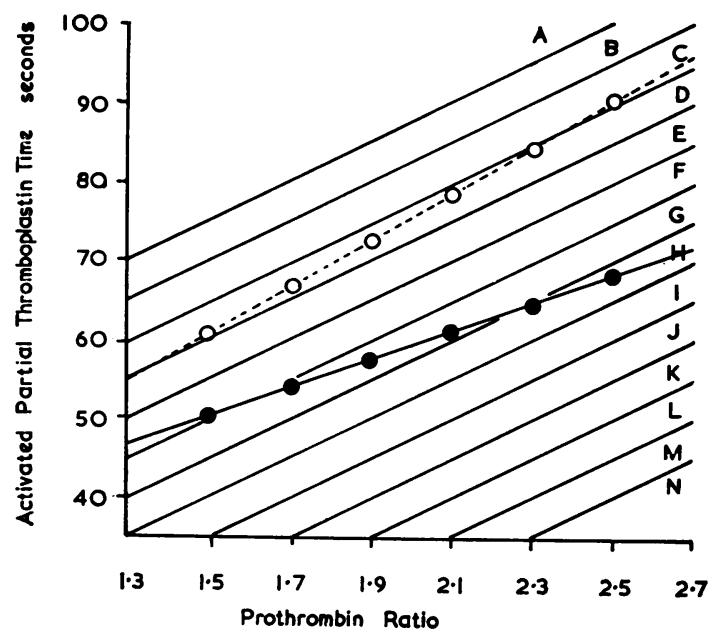

Fig 1 Grid derived from activated partial thromboplastin time/prothrombin time correlations.

Open circles denote linear correlation derived from 70 results from a male patient who has suffered at least four myocardial infarctions, and has been treated with oral anticoagulants for seven years $(r=0.76)$.

Closed circles denote linear correlation derived from 87 results from a female patient who has suffered repeated attacks of thrombophlebitis, and has been treated with oral anticoagulants for seven years $(r=0.69)$.
The $\chi^{2}$ test was used to compare these distributions, a decrease in the activated partial thromboplastin time results relative to the corresponding prothrombin ratios showing as a downward trend on the grid and a 'shift to the right' in the grid reference distribution, and an increase in the activated partial thromboplastin time results relative to the corresponding prothrombin ratios showing as an upward trend on the grid and a 'shift to the left' in the grid reference distribution.

\section{Results}

Comparison of the four major clinical groups revealed no significant difference between results from postmyocardial patients and mitral valve disease patients, and no significant difference between results from patients following venous thrombosis and following cerebrovascular disease (table II). The distribution of results from postmyocardial infarction patients was significantly different from those obtained following venous thrombosis (fig 2). Similarly when results from 34 patients treated for more than 300 days with anticoagulants following venous thrombosis were examined, there was a greater 'shift to the right' of results in the early period of treatment (table II and fig 3). A similar comparison of results in patients following myocardial infarction revealed no significant change during treatment.

To test whether the age of the patient played any part in such changes, results during the first 100 days of treatment following venous thrombosis were arbitrarily separated into results from patients 


\begin{tabular}{|c|c|c|c|}
\hline & Results & $x^{2}$ & $\mathbf{P}$ \\
\hline $\begin{array}{l}\text { Postmyocardial infarction v postvenous thrombosis } \\
\text { Postmyocardial infarction v mitral valve disease } \\
\text { Postvenous thrombosis v cerebrovascular disease } \\
\text { Postvenous thrombosis } 34 \text { patients treated }(15-100) \text { days } v(101-200) \text { days } \\
\left(\begin{array}{l}(101-200) \\
\text { days } v(201-300)\end{array}\right) \text { days } \\
(15-100) \text { days } v(201-300) \text { days } \\
\text { Postvenous thrombosis } 49 \text { patients }(20-49 \text { years) } v 104 \text { patients }(50+\text { years) } \\
\text { Postmyocardial infarction } 42 \text { patients treated }(15-100) \text { days } v(101-200) \text { days } \\
(101-200) \text { days } v(201-300) \text { days }\end{array}$ & $\begin{array}{r}4893 \\
2913 \\
3465 \\
595 \\
357 \\
596 \\
1157 \\
518 \\
324\end{array}$ & $\begin{array}{r}216 \cdot 78 \\
18 \cdot 67 \\
14 \cdot 65 \\
27 \cdot 49 \\
9 \cdot 57 \\
33 \cdot 67 \\
30 \cdot 81 \\
15 \cdot 51 \\
4 \cdot 21\end{array}$ & $\begin{array}{l}<0.001 \\
>0.05 \\
>0.05 \\
<0.01 \\
>0.05 \\
<0.01 \\
<0.01 \\
>0.05 \\
>0.05\end{array}$ \\
\hline
\end{tabular}

Table II Comparison of distribution of results ( $\chi^{2}$ test)

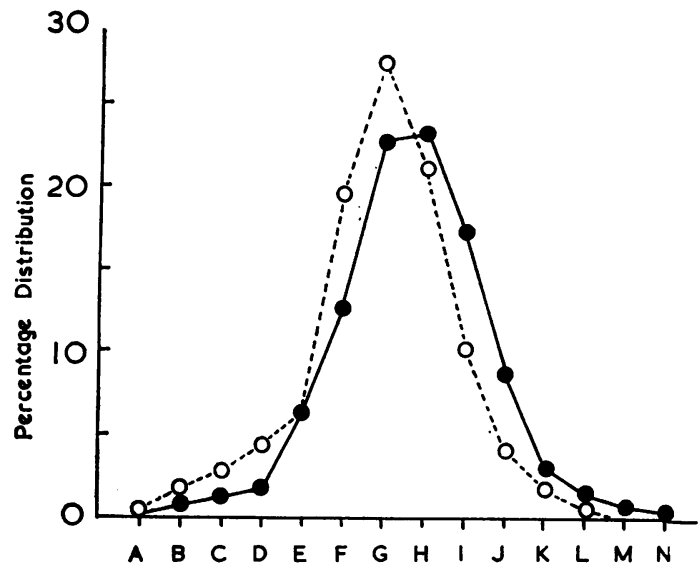

Fig 2

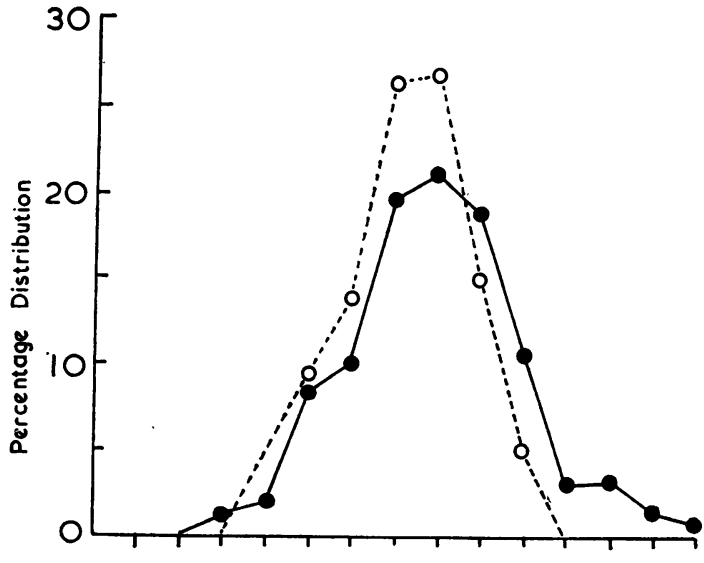

A B C D E

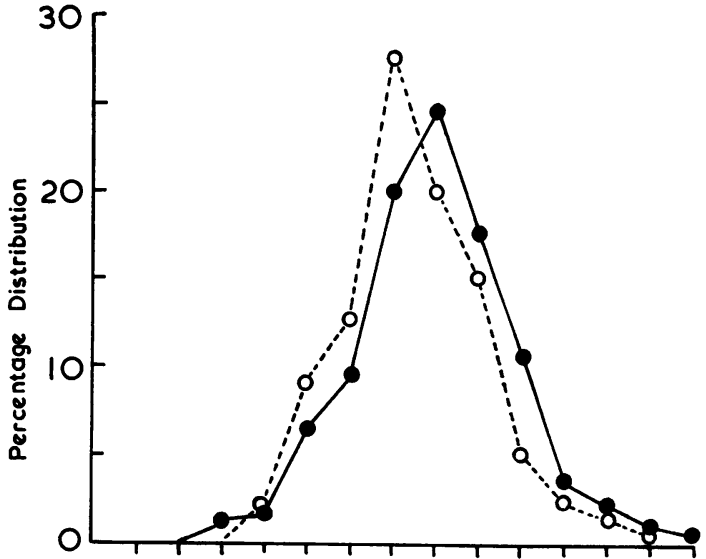

Fig 4

Fig 2 Comparison of distribution of 2108 results from 105 patients following myocardial infarction (average age $53.0 \pm 8.4$ years 1 SD) (open circles) and 2785 results from 253 patients following venous thrombosis (average age $52.8 \pm 13.9$ years $1 S D)$, (closed circles) all treated with oral anticoagulants.

$$
\chi^{2}=216.78 \quad \mathrm{P}=<0.001
$$

Fig 3 Comparison of distribution of 417 pairs of results from 34 patients treated with oral anticoagulants following venous thrombosis, obtained between 15 and 100 days (closed circles) and 178 results obtained from the same patients during 101-200 days of treatment (open circles).

$$
\chi^{2}=27.49 \quad \mathrm{P}=<0.01
$$

Fig 4 Comparison of distribution of 340 pairs of results from 49 patients aged 20-49 years (open circles) and 817 results from 104 patients aged 50 or more years (closed circles). All the patients had suffered from venous thrombosis, and the results were obtained during the first 100 days of treatment with oral anticoagulants.

$$
\chi^{2}=77.89 \quad \mathrm{P}=<0.001
$$

Fig 3 
aged 20-49 years and patients aged 50 years or more, and the results from the older patients showed a greater 'shift to the right' in distribution (fig 4).

\section{Discussion}

After the initial finding of a reduction below normal in the activated partial thromboplastin time following thrombosis or acute haemorrhage or in patients with carcinoma (Eastham and Morgan, 1964) the decrease in the activated partial thromboplastin time relative to the corresponding prothrombin ratio in patients following venous thrombosis when compared with patients following myocardial infarction during long-term anticoagulant therapy (Eastham, 1968) suggested the possibility of laboratory assessment of the efficacy of such treatment, as distinct from the monitoring of anticoagulant dosage. This idea is supported by the present findings of a progressive 'shift to the left' of results from patients following venous thrombosis during treatment towards the pattern of distribution of results found in patients following myocardial infarction and patients with mitral valve disease on prophylactic anticoagulant therapy (fig 3 , table II). It has been known for some time that older patients are more liable to develop venous thrombosis, and it is interesting that the initial 'shift to the right' following venous thrombosis during the first 100 days of treatment is greater in the older age group (fig 4).

The mechanisms whereby the activated partial thromboplastin time is reduced below the normal range after thrombosis and is reduced relative to the prothrombin ratio during anticoagulant therapy following venous thrombosis are not known. It is proposed to continue to analyse further results using the grid, to include a comparison of possible sex differences and also resistance to heparin, since resistance to heparin is increased after thrombosis (Eastham, Perham, and Pocock, 1972; O'Brien, Tulevski, Etherington, Madgwick, Alkjaersig, and Fletcher, 1974; Poller, 1960).

I am grateful to Dr. L. Poller for regular supplies of the British comparative thromboplastin.

\section{References}

Eastham, R. D. (1968). Improved control of long-term anticoagulant therapy. Brit. med. J., 2, 337-340.

Eastham, R. D. (1970). Reaction to long-term oral anticoagulant therapy: a comparison of prothrombin and partial thromboplastin tests. (Abstr.) J. clin. Path., 23, 827.

Eastham, R. D. (1971). Long-term oral anticoagulant therapy and its laboratory assessment. In Proceedings of the 2nd Congress of the International Society on Thrombosis and Haemostasis, Oslo, p. 14.

Eastham, R. D., and Morgan, E. H. (1964). Plasma hypercoagulability in patients with carcinoma and after haemorrhage. Lancet, 2, 543-544.

Eastham, R. D., Perham, T. G. M., and Pocock, P. V. (1972). Warfarin and hydroxyethylrutosides in deep vein thrombosis. (Letter) Brit. med. J. 4, 491.

O'Brien, J. R., Tulevski, V. G., Etherington, M., Madgwick, T., Alkjaersig, N., and Fletch rr, A.P.(1974). Platelet function studies before and after operatiun and the effect of post-operative thrombosis. J. Lab. clin. Med., 83, 342-354.

Poller, L. (1960). The pathogenesis of thrombosis. Postgrad. Med.J., 36, 564-569.

Poller, L. (1970). The British comparative thromboplastin. Assoc. clin. Path.. Broadsheets, 71. 